\title{
Paenibacillus rigui sp. nov., isolated from a freshwater wetland
}

Correspondence

Chi Nam Seong scnu@scnu.ac.kr

\author{
Keun Sik Baik, ${ }^{1}$ Chae Hong Lim, ${ }^{1}$ Han Na Choe, ${ }^{1}$ Eun Mi Kim ${ }^{1,2}$ \\ and Chi Nam Seong ${ }^{1}$
}

\author{
${ }^{1}$ Department of Biological Science, Sunchon National University, Suncheon 540-742, \\ Republic of Korea \\ ${ }^{2}$ Department of Dental Hygiene, Gwangju Health College University, Gwangju 506-701, \\ Republic of Korea
}

\begin{abstract}
A rod-shaped, endospore-forming, Gram-reaction-variable bacterial strain, designated WPCB173 ${ }^{\top}$, was isolated from freshwater collected from the Woopo wetland, Republic of Korea. Based on its phenotypic characteristics and phylogenetic position inferred from 16S rRNA gene sequence analysis, the isolate was identified as being a member of the genus Paenibacillus. Major polar lipids present in strain WPCB $173^{\top}$ included phosphatidylethanolamine and several unidentified phospholipids. The diamino acid found in the cell-wall peptidoglycan was mesodiaminopimelic acid. The predominant menaquinone was MK-7. The major cellular fatty acid was anteiso- $\mathrm{C}_{15 \text { : } 0}(65.2 \%)$. The DNA G $+\mathrm{C}$ content was 48.3 mol\%. Phylogenetic analysis based on 16S rRNA gene sequences indicated that strain WPCB $173^{\top}$ clustered with species of the genus Paenibacillus, its closest neighbours being Paenibacillus chinjuensis WN9 ${ }^{\top}(96.7 \%)$ and Paenibacillus soli $\mathrm{DCY} 3^{\top}(96.4 \%)$. DNA-DNA hybridization of strain WPCB173 ${ }^{\top}$ with $P$. soli $\mathrm{DCY}_{03}{ }^{\top}$ and $P$. chinjuensis $\mathrm{WN9}^{\top}$ showed relatedness values of only 10 and $19 \%$, respectively. On the basis of the phenotypic and phylogenetic evidence, strain WPCB $173^{\top}$ represents a novel species of the genus Paenibacillus, for which the name Paenibacillus rigui sp. nov. is proposed. The type strain of the novel species is WPCB173 ${ }^{\top}\left(=\right.$ KCTC $\left.13282^{\top}=\mathrm{JCM} 16352^{\top}\right)$.
\end{abstract}

The genus Paenibacillus was proposed by Ash et al. (1993) to accommodate the members of 'group 3' within the genus Bacillus. Since then, the transfer of species of the genus Bacillus to this genus and descriptions of novel species have, to date, resulted in 120 species with validly published names being assigned the genus Paenibacillus (http://www. bacterio.cict.fr/p/paenibacillus.html). Members of the genus Paenibacillus share the general characteristics of the genus Bacillus of being aerobic or facultatively anaerobic, endospore-forming and rod-shaped. Members of both genera have physiologically diverse characteristics and some species are known to secrete a variety of extracellular enzymes, such as polysaccharide-hydrolysing enzymes, or to produce polysaccharides (Claus \& Berkeley, 1986; Priest, 1977; Chung et al., 2000; Seo et al., 1999). Species of the genus Paenibacillus have been isolated from a wide range of sources including soil, water, plant rhizospheres, plant materials, food, fodder, faeces and diseased insect larvae (Alexander \& Priest, 1989; Kanzawa et al., 1995; Montefusco et al., 1993;

The GenBank/EMBL/DDBJ accession number for the $16 \mathrm{~S}$ rRNA gene sequence of strain WPCB $173^{\top}$ is EU939688.

Three supplementary figures are available with the online version of this paper.
Nakamura, 1984, 1987; Seldin et al., 1984; Shida et al., 1997; Yoon et al., 1998).

The Woopo wetland $\left(35^{\circ} 33^{\prime} \mathrm{N}, 128^{\circ} 25^{\prime} \mathrm{E}\right)$, located to the east of the Nakdong river, Republic of Korea, was created about 140 million years ago, is surrounded by low-level mountains and has a levee that was built to protect agricultural areas. The wetland types are classified as ' $O$ ', permanent freshwater lakes over $8 \mathrm{ha}$, including large oxbow lakes; and 'Tp', permanent freshwater marshes, pools or ponds below 8 ha, marshes and swamps on inorganic soils with emergent vegetation and that are waterlogged for most of the growing season (http://www. wetlands.org). The bacterial diversity of the wetland was estimated using surface water samples (at $27{ }^{\circ} \mathrm{C}$ and $\mathrm{pH}$ 7.4) taken in July 2000. The bacterial community was composed of members of four phyla; Firmicutes $(49.8 \%$ ), Actinobacteria (32\%), Proteobacteria (13.8\%) and Bacteroidetes (4.4\%) (Baik et al., 2008). In the present study, we describe one bacterial strain that has been identified as a member of the genus Paenibacillus.

Strain WPCB173 ${ }^{\mathrm{T}}$ was isolated using PYGV (Staley, 1968) and R2A agar (Becton Dickinson) at $25{ }^{\circ} \mathrm{C}$ for 7 days. The isolate was routinely cultured on $\mathrm{R} 2 \mathrm{~A}$ agar and preserved at 
$-80{ }^{\circ} \mathrm{C}$ as a suspension in distilled water containing $20 \%$ (w/v) glycerol.

Bacterial DNA preparation, PCR amplification and sequencing of the $16 \mathrm{~S}$ rRNA gene were carried out as described previously (Chun \& Goodfellow, 1995). The identification of phylogenetic neighbours and calculation of pairwise $16 \mathrm{~S}$ rRNA gene sequence similarities were achieved using the EzTaxon server (http://www.eztaxon. org/; Chun et al., 2007). Sequences of the novel isolate and related taxa were aligned using CLUSTAL_X (Thompson et al., 1997) and the alignment was refined using PHYDIT (Chun, 1995). A total of 1407 unambiguously aligned nucleotide positions were used for tree reconstruction. Phylogenetic analysis was performed using the computer packages PHYLIP (Felsenstein, 1993) and PAUP ${ }^{\star} 4.0$ (Swofford, 1998). Phylogenetic trees were inferred using the FitchMargoliash (Fitch \& Margoliash, 1967), maximum-likelihood (Felsenstein, 1993), maximum-parsimony (Fitch, 1971) and neighbour-joining (Saitou \& Nei, 1987) algorithms. Distance matrices for the neighbour-joining and Fitch-Margoliash methods were generated according to the model of Jukes and Cantor (1969). The robustness of the topology in the phylogenetic trees was evaluated by bootstrap analysis (Felsenstein, 1985) of the neighbourjoining method based on 1000 resamplings.

Strain $\mathrm{WPCB}_{173^{\mathrm{T}}}$ showed the highest $16 \mathrm{~S}$ rRNA gene sequence similarity to Paenibacillus chinjuensis WN9 ${ }^{\mathrm{T}}$ (96.7\%) followed by Paenibacillus soli $\mathrm{DCY}^{\mathrm{T}}$ (96.4\%) and showed $<95.7 \%$. similarity to other members of the genus Paenibacillus. The neighbour-joining tree (Fig. 1 and Supplementary Fig. S3, available in IJSEM Online) showed that strain WPCB $173^{\mathrm{T}}$ formed a distinct branch within the clade comprising P. chinjuensis $\mathrm{WN}^{\mathrm{T}}$ and $P$. soli $\mathrm{DCY}^{\mathrm{T}} 3^{\mathrm{T}}$, which was also shown in the Fitch-Margoliash tree (data not shown). On the basis of $16 \mathrm{~S}$ rRNA gene sequence similarity data and the results of the phylogenetic analysis, it is clear that strain $\mathrm{WPCB}_{173}{ }^{\mathrm{T}}$ represents a novel genomic species within the genus Paenibacillus (Wayne et al., 1987) as 16S rRNA gene sequence similarities between strain WPCB $173^{\mathrm{T}}$ and species of the genus Paenibacillus were below the level of similarity typically observed at the species level (97\%; Stackebrandt \& Goebel, 1994).

Growth on various standard bacteriological media was tested by using nutrient agar (NA; Becton Dickinson), tryptic soy agar (TSA; Becton Dickinson) and R2A agar. Cells of strain $\mathrm{WPCB}_{173^{\mathrm{T}}}$ grown on TSA at $30{ }^{\circ} \mathrm{C}$ for 2 days were used for the physiological and biochemical tests. Morphology of the cells was observed using light microscopy (BX50; Olympus) and scanning electron microscopy (S-4800; Hitachi). Endospore formation was observed using phase-contrast microscopy (TMS-F; Nikon). Motility was examined by observing cells grown in wet mounts using a phase-contrast microscope. Flagellation was determined using a transmission electron microscope (CM-20; Philips) with cells cultured for $48 \mathrm{~h}$ in tryptic soy broth (TSB; Becton Dickinson). For this purpose, the cells were negatively stained with $1 \%(\mathrm{w} / \mathrm{v})$ phosphotungstic acid and the grids were examined after being air-dried. The Gram-reaction test was performed on cells grown on TSA at $25{ }^{\circ} \mathrm{C}$ for $1-16$ days by using the bioMérieux Gram stain kit according to the manufacturer's instructions and the Ryu non-staining $\mathrm{KOH}$ method (Powers, 1995). Growth at 0-10\% (w/v) $\mathrm{NaCl}$ (increments of $1 \%$ ) was investigated in TSB prepared according to the manufacturer's instructions except that different amounts of $\mathrm{NaCl}$ were used. Growth at $\mathrm{pH} 4-11$ (increments of 1 $\mathrm{pH}$ unit) was determined in TSB that was adjusted by the addition of $\mathrm{HCl}$ and $\mathrm{NaOH}$. The optimum and range of temperatures for growth were tested on TSA at $4-50{ }^{\circ} \mathrm{C}$. Anaerobic growth was tested on TSA in a jar containing an AnaeroPack-Anaero (Mitsubishi Gas Chemical), which works as oxygen absorber and $\mathrm{CO}_{2}$ generator for up to 10 days. Catalase activity was determined from bubble production in a $3 \%(\mathrm{v} / \mathrm{v})$ aqueous hydrogen peroxide solution. Oxidase activity was tested by using bioMérieux oxidase reagent. Nitrate reduction was tested on TSB containing $0.2 \%$ (w/v) $\mathrm{KNO}_{3}$ (Skerman, 1967). Hydrogen sulfide production was determined on Kligler iron agar (Becton Dickinson). Hydrolysis of carboxymethyl cellulose $(1 \%, \mathrm{w} / \mathrm{v})$, casein $(2 \%$ skim milk, w/v), egg yolk $(10 \%, \mathrm{w} /$ $\mathrm{v})$, starch $(0.2 \%, \mathrm{w} / \mathrm{v})$, Tween $20(1 \%$, w/v), Tween 80

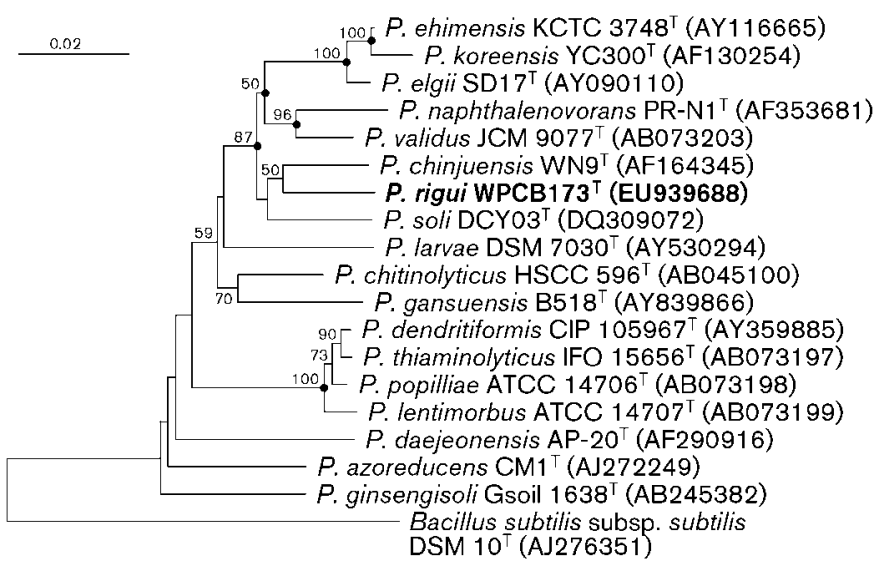

Fig. 1. Neighbour-joining tree based on nearly complete 16S rRNA gene sequences showing relationships between strain WPCB $173^{\top}$ and some related members of the genus Paenibacillus. Percentage bootstrap values $>50 \%$ (based on 1000 resamplings) are given at branch points. Solid circles indicate that the corresponding nodes (groupings) were also recovered in Fitch-Margoliash, maximum-parsimony and maximum-likelihood trees. Bar, 0.02 substitutions per nucleotide position. 
$(1 \%, \mathrm{w} / \mathrm{v})$, L-tyrosine $(0.5 \%, \mathrm{w} / \mathrm{v})$ and xylan $(1 \%, \mathrm{w} / \mathrm{v})$ was tested as described by Smibert \& Krieg (1994). DNase activity was determined with DNase test agar (Becton Dickinson). Other biochemical and enzymic activity tests were performed using API $20 \mathrm{NE}$, API $50 \mathrm{CHB}$ and API ZYM kits (bioMérieux) and a GP2 MicroPlate (Biolog) prepared according to the manufacturer's instructions. Antibiotic resistance was determined after 5 days of incubation at $30{ }^{\circ} \mathrm{C}$ on TSA using the disc diffusion method with commercial antibiotic-impregnated discs (BBL, Becton Dickinson), the results of which were interpreted according to the guidelines set forth by the CLSI (2003).

Cells of strain WPCB $173^{\mathrm{T}}$ stained Gram-reaction-variable (Supplementary Fig. S1a). The $\mathrm{KOH}$ test was negative as was reported previously (Powers, 1995) for Gram-negative bacteria. Vegetative cells were rod-shaped and 0.4 $0.6 \times 2.0-5.0 \mu \mathrm{m}$. Young cells were peritrichously flagellated. Ellipsoidal spores were formed in swollen sporangia (Supplementary Fig. S1b). Strain WPCB $173^{\mathrm{T}}$ was positive for nitrate reduction, $\beta$-galactosidase activity and assimilation of gentiobiose, $\alpha$-D-glucose, maltose, malic acid, Dmannitol, melibiose, potassium gluconate and pyruvic acid, whereas its closest relatives, $P$. chinjuensis $\mathrm{WN}^{\mathrm{T}}$ and $P$. soli $\mathrm{DCY}^{\mathrm{T}}{ }^{\mathrm{T}}$, were negative for these characteristics. Strain WPCB $173^{\mathrm{T}}$ was negative for growth in $2 \% \mathrm{NaCl}(\mathrm{w} / \mathrm{v})$ and at $42{ }^{\circ} \mathrm{C}$, hydrolysis of Tweens 40 and 80 and naphthol-ASB1-phosphohydrolase activity, while $P$. chinjuensis $\mathrm{WN}^{\mathrm{T}}$ and $P$. soli $\mathrm{DCY} 03^{\mathrm{T}}$ were positive for these characteristics. Detailed results of physiological and biochemical tests are given in Table 1 and in the species description.

Cellular fatty acids of cells of strain WPCB $173^{\mathrm{T}}$ grown on TSA for 2 days at $30{ }^{\circ} \mathrm{C}$ were prepared (in duplicate) and analysed by GLC according to the instructions of the Microbial Identification System (MIDI, 1999). Polar lipids were analysed by using standard procedures (Minnikin et al., 1984). Extracted lipids were separated by twodimensional TLC and identified by spraying with appropriate detection reagents (Minnikin et al., 1984; Komagata \& Suzuki, 1987). The isomer type of the diamino acid of the cell wall was analysed according to the method of Komagata \& Suzuki (1987). Respiratory quinones were extracted from $300 \mathrm{mg}$ samples of freeze-dried cells, purified according to the method of Minnikin et al. (1984) and analysed by HPLC as described previously (Kroppenstedt, 1985). The DNA G+C content was calculated using the formula described by Mandel et al. (1970). The DNA sample was prepared in duplicate and the $\mathrm{G}+\mathrm{C}$ content was determined using the thermal denaturation method of Marmur \& Doty (1962). Taxonomic relationships between strain $\mathrm{WPCB}^{\mathrm{T}} 13^{\mathrm{T}}$ and $P$. soli $\mathrm{DCY}^{\mathrm{T}}{ }^{\mathrm{T}}$ and $P$. chinjuensis $\mathrm{WN} 9^{\mathrm{T}}$ were examined further using DNA-DNA hybridization, which was performed using the membrane filter technique with a DIG High Prime DNA Labelling and Detection Starter kit II (Roche) according to the method described in detail by Lee et al. (2003) with the modification that the hybridization temperature used was $55^{\circ} \mathrm{C}$.
Table 1. Differential characteristics of strain WPCB $173^{\top}$ and type strains of related species of the genus Paenibacillus

Taxa: 1, WPCB173 ${ }^{\mathrm{T}} ; 2$, P. chinjuensis $\mathrm{WN} 9^{\mathrm{T}} ; 3$, P. soli $\mathrm{DCY}^{\mathrm{T}}{ }^{\mathrm{T}} .+$, Positive; -, negative; $\mathrm{W}$, weakly positive.

\begin{tabular}{|c|c|c|c|}
\hline Characteristic & $1^{*}$ & 2 & 3 \\
\hline Anaerobic growth & - & + & - \\
\hline Motility & + & + & - \\
\hline Oxidase & + & + & - \\
\hline Nitrate reduction & + & - & - \\
\hline$\beta$-Galactosidase ${ }^{*}$ & + & - & - \\
\hline \multicolumn{4}{|l|}{ Growth at/in: } \\
\hline $2 \%(\mathrm{w} / \mathrm{v}) \mathrm{NaCl}$ & - & - & + \\
\hline $42{ }^{\circ} \mathrm{C}$ & - & + & + \\
\hline $\mathrm{pH} 5-6$ & + & + & - \\
\hline \multicolumn{4}{|l|}{ Hydrolysis of ${ }^{*}$ : } \\
\hline DNA & - & + & - \\
\hline Tween 80 & - & + & + \\
\hline \multicolumn{4}{|l|}{ Assimilation of (API $20 \mathrm{NE})^{*}$ : } \\
\hline L-Arabinose & + & - & + \\
\hline Malic acid & + & - & - \\
\hline Maltose & + & + & + \\
\hline D-Mannitol & + & - & - \\
\hline D-Mannose & + & + & - \\
\hline Postassium gluconate & + & - & - \\
\hline \multicolumn{4}{|l|}{ Enzyme activities (API ZYM)*: } \\
\hline Alkaline phosphatase & - & + & - \\
\hline Esterase $(\mathrm{C} 4)$ & $\mathrm{w}$ & - & - \\
\hline$\alpha$-Glucosidase & + & - & - \\
\hline Leucine arylamidase & + & - & + \\
\hline Naphthol-AS-B1-phosphohydrolase & - & + & + \\
\hline \multicolumn{4}{|l|}{ Utilization of (Biolog GP2)*: } \\
\hline L-Alanyl glycine & - & + & - \\
\hline Gentiobiose & + & - & - \\
\hline$\alpha$-D-Glucose & + & - & - \\
\hline Maltose & + & + & - \\
\hline Melibiose & + & - & - \\
\hline Monomethyl succinate & + & + & - \\
\hline Palatinose & + & + & - \\
\hline Pyruvic acid & + & - & - \\
\hline Trehalose & + & + & - \\
\hline Turanose & + & + & - \\
\hline Tween 40 & - & - & + \\
\hline DNA G $+\mathrm{C}$ content $(\mathrm{mol} \%)$ & 48.3 & 53 & 56.6 \\
\hline
\end{tabular}

${ }^{\star}$ Data from this study. Other data from Yoon et al. (2002) and Park et al. (2007).

The major fatty acids of strain WPCB $173^{\mathrm{T}}$ included the branched saturated fatty acids anteiso- $\mathrm{C}_{15: 0}(65.2 \%)$, iso$\mathrm{C}_{15: 0}(9.3 \%)$, iso- $\mathrm{C}_{16: 0}(5.4 \%)$ and anteiso- $\mathrm{C}_{17: 0}(3.1 \%)$ and the straight-chain saturated fatty acids $\mathrm{C}_{15: 0}(5.7 \%)$ and $\mathrm{C}_{16: 0}(3.6 \%)$. The fatty acid profile of strain WPCB $173^{\mathrm{T}}$ was similar to that of related species of the genus Paenibacillus (Table 2). The polar lipids patterns were characterized by the presence of phosphatidylethanolamine, phosphatidylglycerol and several unidentified phospholipids (Supplementary Fig. S2). The diamino acid 
in the cell-wall peptidoglycan of strain $\mathrm{WPCB} 173^{\mathrm{T}}$ was meso-diaminopimelic acid. The predominant isoprenoid quinone was menaquinone with seven isoprene units (MK7). The DNA G+C content of strain $\mathrm{WPCB} 173^{\mathrm{T}}$ was $48.3 \mathrm{~mol} \%$. Genomic DNA-DNA hybridization of strain $\mathrm{WPCB}_{173^{\mathrm{T}}}$ with P. soli $\mathrm{DCY}^{\mathrm{T}} 3^{\mathrm{T}}$ and P. chinjuensis $\mathrm{WN} 9^{\mathrm{T}}$ showed relatedness values of only 10 and $19 \%$, respectively. The levels of genetic relatedness according to DNADNA hybridization experiments were less than $70 \%$, the recommended threshold for the delineation of bacterial species (Wayne et al., 1987), which lead to the conclusion that strain $\mathrm{WPCB} 173^{\mathrm{T}}$ represents a novel species.

Based on the phylogenetic, genomic and phenotypic evidence, strain WPCB $173^{\mathrm{T}}$ represents a novel species of the genus Paenibacillus, for which the name Paenibacillus rigui sp. nov. is proposed.

\section{Description of Paenibacillus rigui sp. nov.}

Paenibacillus rigui (ri'gu.i. L. gen. n. rigui of a well-watered place, referring to where the type strain was isolated).

Cells of strain $\mathrm{WPCB}_{173^{\mathrm{T}}}$ are Gram-reaction-variable, motile, rod-shaped, $0.4-0.6 \times 2-5 \mu \mathrm{m}$ and occur singularly or in chains. Produces ellipsoidal endospores that lie in the subterminal position and usually cause the sporangia to

Table 2. Cellular fatty acid profiles (\%) of strain WPCB $173^{\top}$ and type strains of related species of the genus Paenibacillus

Taxa: 1 , WPCB $173^{\mathrm{T}} ; 2$, P. chinjuensis $\mathrm{WN} 9^{\mathrm{T}} ; 3$, P. soli $\mathrm{DCY}^{\mathrm{T}} 3^{\mathrm{T}}$. Cells of all strains were harvested after cultivation at $30{ }^{\circ} \mathrm{C}$ on TSA medium for 2 days. -, Not detected. All data were obtained in this study.

\begin{tabular}{|lccc|}
\hline Fatty acid & $\mathbf{1}$ & $\mathbf{2}$ & $\mathbf{3}$ \\
\hline Straight-chain saturated & & & \\
$\mathrm{C}_{13: 0}$ & 0.3 & - & - \\
$\mathrm{C}_{14: 0}$ & 0.9 & 0.6 & 2.0 \\
$\mathrm{C}_{15: 0}$ & 5.7 & 3.1 & 9.2 \\
$\mathrm{C}_{16: 0}$ & 3.6 & 6.5 & 8.7 \\
$\mathrm{C}_{17: 0}$ & 0.6 & - & 0.4 \\
$\mathrm{C}_{18: 0}$ & 0.7 & 0.5 & 0.5 \\
Hydroxy & & & \\
$\mathrm{C}_{13: 0} 2-\mathrm{OH}$ & - & 0.6 & - \\
Branched saturated & & & \\
iso- $\mathrm{C}_{13: 0}$ & 0.2 & - & - \\
iso- $\mathrm{C}_{14: 0}$ & 2.9 & 1.6 & 2.8 \\
iso- $\mathrm{C}_{15: 0}$ & 9.3 & 3.4 & 11.1 \\
iso- $\mathrm{C}_{16: 0}$ & 5.4 & 8.2 & 6.5 \\
iso- $\mathrm{C}_{17: 0}$ & 2.0 & 1.6 & 1.5 \\
anteiso- $\mathrm{C}_{13: 0}$ & 0.2 & - & - \\
anteiso- $\mathrm{C}_{15: 0}$ & 65.2 & 66.7 & 53.8 \\
anteiso- $\mathrm{C}_{17: 0}$ & 3.1 & 7.1 & 2.4 \\
Summed feature $3^{*}$ & - & - & 1.2 \\
& & & \\
\hline
\end{tabular}

* Summed features represent groups of two fatty acids that could not be separated by GLC in the MIDI system. Summed feature 3 comprises $\mathrm{C}_{16: 1} \omega 7 c$ and/or iso- $\mathrm{C}_{15: 0} 2-\mathrm{OH}$. swell. Colonies grown on TSA plates for 2 days at $30{ }^{\circ} \mathrm{C}$ are circular, $\sim 1 \mathrm{~mm}$ in diameter, opaque, cream, convex and have entire margins. Does not grow under anaerobic conditions. Grows at $15-37{ }^{\circ} \mathrm{C}$ (optimum $30{ }^{\circ} \mathrm{C}$ ), $\mathrm{pH} 5-8$ (optimum $\mathrm{pH} 6-7)$ and in up to $1 \%(\mathrm{w} / \mathrm{v}) \mathrm{NaCl}$. Positive for nitrate reduction. Hydrogen sulfide is not produced. Catalase- and oxidase-positive. Starch and Tween 20 are hydrolysed but carboxymethyl cellulose, casein, DNA, egg yolk, gelatin, Tween 80 , L-tyrosine and xylan are not. In the API 20NE system, positive for nitrate reduction, fermentation of $\mathrm{D}$-glucose, aesculin hydrolysis ( $\beta$-glucosidase), $\beta$ galactosidase activity and assimilation of D-glucose, Larabinose, maltose, D-mannitol, D-mannose and malic acid, but negative for indole production, arginine dihydrolase, gelatin hydrolysis and urease activities and assimilation of $\mathrm{N}$-acetylglucosamine, capric acid, adipic acid, trisodium citrate and phenylacetic acid. In the API ZYM system, $\alpha$-galactosidase, $\beta$-galactosidase, $\alpha$-glucosidase and leucine arylamidase activities are present and acid phosphatase, esterase (C4) and esterase lipase (C8) are weakly active. In the Biolog GP2 Microplate (Biolog) system, the following substrates are assimilated: dextrin, gentiobiose, $\alpha$-D-glucose, maltose, maltotriose, melibiose, palatinose, sucrose, trehalose, turanose, monomethyl succinate and pyruvic acid; the following substrates are weakly assimilated: glycogen, L-arabinose, D-galactose, Dmannitol, methyl- $\alpha$-D-glucoside, raffinose, D-ribose, Dsorbitol, D-xylose, acetic acid and methyl pyruvate; other substrates are not assimilated. Cells are sensitive to ( $\mu$ g per disc, unless otherwise indicated): amikacin (30), ampicillin (10), chloramphenicol (30), erythromycin (15), gentamicin (10), kanamycin (30), nalidixic acid (30), penicillin (10 IU), polymyxin B (300 IU), streptomycin (10) tetracycline (30) and vancomycin (30). Other physiological and biochemical characteristics are given in Table 1. The major fatty acid is anteiso- $\mathrm{C}_{15: 0}$. The major polar lipids are phosphatidylethanolamine and unidentified phospholipids. The diamino acid in the cell-wall peptidoglycan is meso-diaminopimelic acid. The predominant isoprenoid quinone is MK-7.

The type strain, $\mathrm{WPCB}_{173^{\mathrm{T}}}\left(=\mathrm{KCTC} 13282^{\mathrm{T}}=\mathrm{JCM}\right.$ $\left.16352^{\mathrm{T}}\right)$, was isolated from freshwater collected from the Woopo wetland, Republic of Korea. The DNA G+C content of the type strain is $48.3 \mathrm{~mol} \%$.

\section{Acknowledgements}

This research was supported by the 21C Frontier Microbial Genomics and Applications Center Program, Ministry of Education, Science \& Technology, Republic of Korea. We are indebted to the Korea Basic Science Institute, Suncheon, Republic of Korea, for scanning electron microscopy analysis.

\section{References}

Alexander, B. \& Priest, F. G. (1989). Bacillus glucanolyticus, a new species that degrades a variety of $\beta$-glucans. Int J Syst Bacteriol 39, $112-115$. 
Ash, C., Priest, F. G. \& Collins, M. D. (1993). Molecular identification of rRNA group 3 bacilli (Ash, Farrow, Wallbanks and Collins) using a PCR probe test. Proposal for the creation of a new genus Paenibacillus. Antonie van Leeuwenhoek 64, 253-260.

Baik, K. S., Park, S. C., Kim, E. M., Bae, K. S., Ahn, J. H., Ka, J. O., Chun, J. \& Seong, C. N. (2008). Diversity of bacterial community in freshwater of Woopo wetland. J Microbiol 46, 647-655.

Chun, J. (1995). Computer-assisted classification and identification of actinomycetes. $\mathrm{PhD}$ thesis, University of Newcastle.

Chun, J. \& Goodfellow, M. (1995). A phylogenetic analysis of the genus Nocardia with $16 \mathrm{~S}$ rRNA gene sequences. Int J Syst Bacteriol 45, 240-245.

Chun, J., Lee, J.-H., Jung, Y., Kim, M., Kim, S., Kim, B. K. \& Lim, Y. W. (2007). EzTaxon: a web-based tool for the identification of prokaryotes based on $16 \mathrm{~S}$ ribosomal RNA gene sequences. Int J Syst Evol Microbiol 57, 2259-2261.

Chung, Y. R., Kim, C. H., Hwang, I. \& Chun, J. (2000). Paenibacillus koreensis sp. nov., a new species that produces an iturin-like antifungal compound. Int J Syst Evol Microbiol 50, 1495-1500.

Claus, D. \& Berkeley, R. C. W. (1986). Genus Bacillus Cohn 1872. In Bergey's Manual of Systematic Bacteriology, vol. 2, pp. 1105-1139. Edited by P. H. A. Sneath, N. S. Mair, M. E. Sharpe \& J. G. Holt. Baltimore: Williams \& Wilkins.

CLSI (2003). Performance standards for antimicrobial disk susceptibility tests, 8th edn. Approved Standard M2-A8. Wayne, PA: Clinical Laboratory Standards Institute.

Felsenstein, J. (1985). Confidence limits on phylogenies: an approach using the bootstrap. Evolution 39, 783-791.

Felsenstein, J. (1993). PHYLIP (phylogeny inference package), version 3.5c. Distributed by the author. Department of Genome Sciences, University of Washington, Seattle, USA.

Fitch, W. M. (1971). Toward defining the course of evolution: minimum change for a specific tree topology. Syst Zool 20, 406-416.

Fitch, W. M. \& Margoliash, E. (1967). Construction of phylogenetic trees. Science 155, 279-284.

Jukes, T. H. \& Cantor, C. R. (1969). Evolution of protein molecules. In Mammalian Protein Metabolism, pp. 21-132. Edited by $\mathrm{H}$ N. Munro. New York: Academic Press.

Kanzawa, Y., Harada, A., Takeuchi, M., Yokota, A. \& Harada, T. (1995). Bacillus curdlanolyticus sp. nov. and Bacillus kobensis sp. nov., which hydrolyze resistant curdlan. Int J Syst Bacteriol 45, 515-521.

Komagata, K. \& Suzuki, K. (1987). Lipids and cell-wall analysis in bacterial systematics. Methods Microbiol 19, 161-207.

Kroppenstedt, R. M. (1985). Fatty acid and menaquinone analysis of actinomycetes and related organisms. In Chemical Methods in Bacterial Systematics, pp. 173-199. Edited by M. Goodfellow \& D. E. Minnikin. London: Academic Press.

Lee, J.-S., Lee, K. C., Pyun, Y.-R. \& Bae, K. S. (2003). Arthrobacter koreensis sp. nov., a novel alkalitolerant bacterium from soil. Int J Syst Evol Microbiol 53.

Mandel, M., Igambi, L., Bergendahl, J., Dodson, M. L., Jr \& Scheltgen, E. (1970). Correlation of melting temperature and cesium chloride buoyant density of bacterial deoxyribonucleic acid. J Bacteriol 101, 333-338.

Marmur, J. \& Doty, P. (1962). Determination of the base composition of deoxyribonucleic acid from its thermal denaturation temperature. J Mol Biol 5, 109-118.

MIDI (1999). Sherlock Microbial Identification System Operating Manual, version 3.0. Newark, DE: MIDI Inc.
Minnikin, D. E., O'Donnell, A. G., Goodfellow, M., Alderson, G., Athayle, M., Schaal, A. \& Parlett, J. H. (1984). An integrated procedure for the extraction of bacterial isoprenoid quinones and polar lipids. J Microbiol Methods 2, 233-241.

Montefusco, A., Nakamura, L. K. \& Labeda, D. P. (1993). Bacillus peoriae sp. nov. Int J Syst Bacteriol 43, 388-390.

Nakamura, L. K. (1984). Bacillus amylolyticus sp. nov., nom. rev., Bacillus lautus sp. nov., nom. rev., Bacillus pabuli sp. nov., nom. rev., and Bacillus validus sp. nov., nom. rev. Int J Syst Bacteriol 34, 224226.

Nakamura, L. K. (1987). Bacillus alginolyticus sp. nov. and Bacillus chondroitinus sp. nov., two alginate-degrading species. Int J Syst Bacteriol 37, 284-286.

Park, M.-J., Kim, H.-B., An, D.-S., Yang, H.-C., Oh, S.-T., Chung, H.-J. \& Yang, D.-C. (2007). Paenibacillus soli sp. nov., a xylanolytic bacterium isolated from soil. Int J Syst Evol Microbiol 57, 146-150.

Powers, E. M. (1995). Efficacy of the Ryu nonstaining $\mathrm{KOH}$ technique for rapidly determining Gram reactions of food-borne and waterborne bacteria and yeasts. Appl Environ Microbiol 61, 3756-3758.

Priest, F. G. (1977). Extracellular enzyme synthesis in the genus Bacillus. Bacteriol Rev 41, 711-753.

Saitou, N. \& Nei, M. (1987). The neighbor-joining method: a new method for reconstructing phylogenetic trees. Mol Biol Evol 4, 406425.

Seldin, L., van Elsas, J. D. \& Penido, E. G. C. (1984). Bacillus azotofixans sp. nov., a nitrogen-fixing species from Brazilian soils and grass roots. Int J Syst Bacteriol 34, 451-456.

Seo, W.-T., Kahng, G.-G., Nam, S.-H., Choi, S.-D., Suh, H.-H., Kim, S.-W. \& Park, Y.-H. (1999). Isolation and characterization of a novel exopolysaccharide-producing Paenibacillus sp. WN9 KCTC 8951P. J Microbiol Biotechnol 9, 820-825.

Shida, O., Takagi, H., Kadowaki, K., Nakamura, L. K. \& Komagata, K. (1997). Emended description of Paenibacillus amylolyticus and description of Paenibacillus illinoisensis sp. nov. and Paenibacillus chibensis sp. nov. Int J Syst Bacteriol 47, 299-306.

Skerman, V. B. D. (1967). A Guide to the Identification of the Genera of Bacteria, 2nd edn. Baltimore: Williams \& Wilkins.

Smibert, R. M. \& Krieg, N. R. (1994). General characterization. In Methods for General and Molecular Bacteriology, pp. 607-654. Edited by P. Gebhardt, R. G. E. Murray, W. A. Wood \& N. R. Krieg. Washington, DC: American Society for Microbiology.

Stackebrandt, E. \& Goebel, B. M. (1994). Taxonomic note: a place for DNA-DNA reassociation and 16S rRNA sequence analysis in the present species definition in bacteriology. Int J Syst Bacteriol 44, 846849.

Staley, J. T. (1968). Prosthecomicrobium and Ancalomicrobium: new prosthecate freshwater bacteria. J Bacteriol 95, 1921-1942.

Swofford, D. L. (1998). PAUP*: Phylogenetic analysis using parsimony (and other methods), version 4. Sunderland, MA: Sinauer Associates.

Thompson, J. D., Gibson, T. J., Plewniak, F., Jeanmougin, F. \& Higgins, D. G. (1997). The CLUSTAL_X windows interface: flexible strategies for multiple sequence alignment aided by quality analysis tools. Nucleic Acids Res 25, 4876-4882.

Wayne, L. G., Brenner, D. J., Colwell, R. R., Grimont, P. A. D., Kandler, O., Krichevsky, M. I., Moore, L. H., Moore, W. E. C., Murray, R. G. E. \& other authors (1987). International Committee on Systematic Bacteriology. Report of the ad hoc committee on reconciliation of approaches to bacterial systematics. Int $J$ Syst Bacteriol 37, 463-464. 
Yoon, J.-H., Yim, D. K., Lee, J.-S., Shin, K.-S., Sato, H. H., Lee, S. T., Park, Y. K. \& Park, Y.-H. (1998). Paenibacillus campinasensis sp. nov., a cyclodextrin-producing bacterium isolated in Brazil. Int $J$ Syst Bacteriol 48, 833-837.
Yoon, J.-H., Seo, W.-T., Shin, Y. K., Kho, Y. H., Kang, K. H. \& Park, Y.-H. (2002). Paenibacillus chinjuensis sp. nov., a novel exopolysaccharide-producing bacterium. Int J Syst Evol Microbiol 52, 415-421. 